\title{
Transfer of multiple loci of donor's genes to induce recipient tolerance in organ transplantation
}

\author{
TONG LI ${ }^{1,2^{*}}$, WENQIAN ZHANG ${ }^{1 *}$, QING XU ${ }^{3}$, SHENTAO $\mathrm{LI}^{4}, \mathrm{XUEHONG} \mathrm{TONG}{ }^{3}, \mathrm{JIE} \mathrm{DING}^{5}$, \\ HUI LI ${ }^{1}$, SHENGCAI HOU ${ }^{1}$, ZHIDONG XU ${ }^{2}$, DAVID M. JABLONS ${ }^{2}$ and LIANG YOU ${ }^{2}$ \\ ${ }^{1}$ Thoracic Surgery Department, Beijing Chao-Yang Hospital, Capital Medical University, Beijing 100020, P.R. China; \\ ${ }^{2}$ Thoracic Oncology Laboratory, Department of Surgery, Helen Diller Family Comprehensive Cancer Center, \\ University of California San Francisco, San Francisco, CA 94143-1724, USA; ${ }^{3}$ Medical Experiment and Test Center; \\ ${ }^{4}$ Department of Molecular Biology, Capital Medical University, Beijing 100054; ${ }^{5}$ Experimental Center, \\ Beijing Chao-Yang Hospital, Capital Medical University, Beijing 100020, P.R. China
}

Received March 10, 2017; Accepted February 2, 2018

DOI: $10.3892 /$ etm.2018.6058

\begin{abstract}
Donor organ rejection remains a significant problem. The present study aimed to assess whether transferring a donor's major histocompatibility complex (MHC) genes to the recipient could mitigate rejection in organ transplantation. Seven loci of MHC genes from donor mice were amplified and ligated into vectors; the vectors either contained one K locus, seven loci or were empty (control). The vectors were subsequently injected into the thymus of recipients (in heterotransplants, recipient rats received the vector containing one $\mathrm{K}$ locus), following which donor mouse hearts were transplanted. Following the transplantation of allograft and heterograft, electrocardiosignals were viable for a significantly longer duration in recipient mice and rats receiving the donor histocompatibility-2 complex $(\mathrm{H}-2)^{\mathrm{d}}$ genes compared with those in controls, and in mice that received seven vectors compared with those receiving one vector. Mixed lymphocyte cultures containing cells from these recipients proliferated significantly less compared with mixed lymphocyte cultures containing controls. Also, hearts from $\mathrm{H}-2^{\mathrm{d}}$ genes-treated recipients demonstrated less lymphocyte infiltration and
\end{abstract}

Correspondence to: Dr Tong Li, Thoracic Surgery Department, Beijing Chao-Yang Hospital, Capital Medical University, 8 Gongtinan Road, Chaoyang, Beijing 100020, P.R. China

E-mail: li-tong-724@sina.com

Dr Liang You, Thoracic Oncology Laboratory, Department of Surgery, Helen Diller Family Comprehensive Cancer Center, University of California San Francisco, 2340 Sutter Street N221, Campus Box 1724, San Francisco, CA 94143-1724, USA

E-mail: liang.you@ucsfmedctr.org

*Contributed equally

Key words: transplantation, major histocompatibility complex, thymus necrosis compared with the control recipient. The present study concluded that allograft and heterograft rejection may be mitigated by introducing the donor's MHC into the recipient; transferring seven loci has been demonstrated to be more effective than transferring one locus.

\section{Introduction}

Donor organ rejection remains a significant problem for patients receiving transplants $(1,2)$. Pharmacological suppression of immune responses can suppress the rejection process, but the resultant nonspecific suppression of immune responses can lead to a variety of problems, including tumor and infection $(3,4)$. To improve graft survival rates and eliminate the requirement for immunosuppression, donor-specific transplant tolerance must be achieved $(5,6)$. Therefore, a treatment protocol in which the organ recipient is induced to recognize the donor tissue as 'self' would be highly desirable.

The major histocompatibility complex (MHC) is the principal system responsible for recognizing transplanted allogeneic or heterogeneous tissues by the immune system $(7,8)$. The MHC is composed of a series of genes and produces two classes of cell surface glycoproteins and specific serum proteins (MHC class I, II and III molecules) $(9,10)$. Since a discrepancy between the donor's MHC antigen and that of the recipient leads to rejection (10), improving MHC compatibility is desirable (11). It was hypothesized that if the donor's MHC genes could be introduced into and expressed by the recipient, tolerance may be induced.

$\mathrm{T}$ cells serve a key role in the immune system and in transplantation rejection. Following the development of the cells in the bone marrow, $\mathrm{T}$ cells undergo positive and negative selection, interact with MHC antigen in the thymus, then differentiate and mature (12-14). Through the process of negative selection, $\mathrm{T}$ cells that react with self-MHC antigen are removed by apoptosis (15). It was therefore surmised that if the donor's MHC were transferred into a recipient's thymus, apoptosis would also be induced in $\mathrm{T}$ cells that react to the expressed donor MHC antigen. 
In mice, MHC is also termed mouse histocompatibility-2 complex(H-2). This gene complex includes K, D, L, I and $\mathrm{S}$ loci. The K, D and L loci code for the MHC class I antigen, which is expressed on the surface of various types of cells and causes strong rejection following transplantation. The I region, which includes $\mathrm{A} \alpha, \mathrm{A} \beta, \mathrm{E} \alpha$ and $\mathrm{E} \beta$ loci, codes for the MHC class II antigen, which is expressed on the surface of immune cells (12). The S locus is MHC class III gene that codes for specific serum proteins (12). The $\mathrm{K}$ locus is the most important of the three MHC class I loci and antigens of this class are present on the surface of nearly all cells in the mouse (16). For these reasons, a previous study by our group demonstrated that the rejection of transplanted hearts was mitigated and the survival time of transplanted hearts were prolonged following the transfer of a mouse donor's $\mathrm{K}$ locus into a mouse recipient's thymus (17). However, since the $\mathrm{K}$ locus is only a part of the MHC gene complex, the present study aimed to investigate whether transferring all of a donor's loci of the MHC I and II genes into a recipient would be more effective in mitigating rejection and improving graft survival time. In addition, to examine heterograft effects, mouse donor $\mathrm{K}$ loci were also transferred into rats.

\section{Materials and methods}

Animals. Experiments were performed using a total of 45 6- to 8-week-old male and female mice (weight 20-25 g) and a total of 20 8- to 10-week-old male and female rats (weight, 200-300 g). The animals (Charles River Laboratories, Beijing, China) were fed in the animal lab of Capital Medical University and maintained at $20-26^{\circ} \mathrm{C}$ with a level 7 air cleanliness, a $12 \mathrm{~h} \mathrm{light/dark} \mathrm{cycle} \mathrm{and} \mathrm{daily} \mathrm{access} \mathrm{to} \mathrm{food}$ and water. Balb/c mice (the haploid was $\mathrm{H}-2^{\mathrm{d}}$ ) were used as donors, and C57BL/6 mice $\left(\mathrm{H}-2^{\mathrm{b}}\right)$ and Sprague Dawley rats were used as recipients. All experiments were approved by the Capital Medical University Institutional Animal Care and Use Committee (Beijing, China).

Materials. AMV reverse transcriptase and pCI-neo vector were purchased from Promega Corporation (Madison, WI, USA). Mouse anti-H-2 ${ }^{\mathrm{d}}-\mathrm{K}$ (cat. no. BE0104; clone HB159) and anti-H-2 ${ }^{\mathrm{d}}-\mathrm{D}$ (cat. no. BE0180; clone 34-1-2S) antibodies were purchased from Bio X Cell (West Lebanon, NH, USA). The MTT kit was purchased from Fitzgerald Industries International (North Acton, MA, USA). The primers were obtained from Invitrogen (Thermo Fisher Scientific, Inc., Waltham, USA).

Preparation of donor $\mathrm{H}-2^{d}$ gene. Total RNA was extracted from the donors' livers using an RNAprep pure kit (for Tissue) (DP431) (Tiangen Biotech Co., Ltd., Beijing, China) and then reverse transcribed to obtain cDNA using AMV reverse transcriptase (RT) and an AMV reverse transcriptase buffer (10 mM dNTP mixture); the two experiments were performed according to the manufacturer's protocol at $42^{\circ} \mathrm{C}$ for $60 \mathrm{~min}$. The donor $\mathrm{H}^{-2}{ }^{\mathrm{d}}$ gene was amplified by nested polymerase chain reaction (PCR). For the first PCR step, the primers were designed according to the $5^{\prime}$ and $3^{\prime}$ untranslated region in mRNA of every locus. cDNA served as the templates. The PCR protocol included pre-degeneration for $3 \mathrm{~min}$ at $94^{\circ} \mathrm{C}$, followed by 30 cycles of degeneration at $94^{\circ} \mathrm{C}$ for $30 \mathrm{sec}$, annealing at $55^{\circ} \mathrm{C}$ for $30 \mathrm{sec}$, and elongation at $72^{\circ} \mathrm{C}$ for $2 \mathrm{~min}$. As an internal reference, mouse $\beta$-actin mRNA was amplified using primers 5'-CCCCATTGAACATGGCATTG-3' and 5'-ACGACCAGAGGCATACAGG-3'. The reaction was run using Taq Platinum PCR MasterMix or pfu MasterMix (Tiangen Biotech Co., Ltd.).

The second PCR analysis was performed using the product of the first PCR as the template. The primers were designed according to the $5^{\prime}$ and $3^{\prime}$ end of the coding sequence in mRNA of every locus. The primers are indicated in Table I. The PCR protocol was identical to that used in the first step. The product of the second PCR step was retrieved by electrophoresis on a $1 \%$ agarose gel (visualized by $0.5 \mu \mathrm{g} / \mathrm{ml}$ ethidium bromide) and verified by sequence analysis using NextGENe 2.3 (SoftGenetics, LLC, State College, PA, USA).

Construction of the expression vector. The retrieved $\mathrm{H}-2$ DNA fragments of each locus, $\mathrm{K}, \mathrm{D}, \mathrm{L}, \mathrm{A} \alpha, \mathrm{A} \beta, \mathrm{E} \alpha$ and $\mathrm{E} \beta$ were cloned into the pBS-T vector (50 ng $/ \mu \mathrm{l}$; Tiangen Biotech Co., Ltd.). Escherichia coli (E. coli) TOP-10 cells (Tiangen Biotech Co., Ltd.) were transformed using recombinant DNA and vector. The competent TOP-10 cells were combined with recombinant DNA and the vector on ice for $20 \mathrm{~min}$, heated to $42^{\circ} \mathrm{C}$ for $90 \mathrm{sec}$, put on ice again for $3 \mathrm{~min}$, added to the Luria-Bertani (LB) medium (Tiangen Biotech Co., Ltd.) and agitated for $1 \mathrm{~h}$ at $37^{\circ} \mathrm{C}$. Blue-white screening (with Ampicillin, $100 \mathrm{mg} / \mathrm{l}$ in LB medium) and PCR (by the same protocol as the second PCR above) were performed to select clones. Selected colonies were then cultivated until the cells were harvested and the plasmid was extracted. Following this, recombinant DNA digested with endonucleases Xhol and EcoR1, and ligated into pCI-neo (all Promega Corporation), yielding pCI-neo-H-2K ${ }^{\mathrm{d}}$, pCI-neo-H-2 $\mathrm{D}^{\mathrm{d}}$, pCI-neo-H-2 $\mathrm{L}^{\mathrm{d}}$, pCI-neo-H-2 $A \alpha^{d}$, pCI-neo-H-2A $\beta^{d}$, pCI-neo-H-2E $\alpha^{d}$ and pCI-neo-H-2E $\beta^{d}$. All the aforementioned recombinant DNA were cloned into $E$. coli TOP-10 cells as above.

Thymus injection and heart transplantation. A total of 45 recipient mice were randomly divided into three groups $(\mathrm{n}=15 /$ group) and received plasmid injections with pCI-neo-H- $2 \mathrm{~K}^{\mathrm{d}}$, seven vectors with all seven loci of the $\mathrm{H}-2^{\mathrm{d}}$ gene or an empty vector, which was used as a control. A total of 20 recipient rats were randomly divided ( $n=10 /$ group) to receive either pCI-neo-H- $2 \mathrm{~K}^{\mathrm{d}}$ or empty vector, which was used as a control. The mouse and rat recipients were first anesthetized using $5 \%$ chloral hydrate (Tiangen Biotech Co., Ltd.) at $350 \mathrm{mg} /$ $\mathrm{kg}$. The mice and rats stopped moving following the administration of anesthesia, but their eyes were usually opened. Palpebral reflex, toe pinch reflex and corneal reflex tests were performed to monitor the depth of anesthesia. Using an ultrasound for guidance, the thymi of the animals were punctured (Fig. 1A-D). All recipients in the mouse and rat control groups were injected with $0.7 \mu \mathrm{g}$ empty pCI-neo vectors $+1.4 \mu 1$ lipofectin (Invitrogen, Thermo Fisher Scientific, Inc.) [diluted with Dulbecco's modified Eagle's medium (DMEM; Gibco; Thermo Fisher Scientific, Inc.) up to $70 \mu \mathrm{l}]$. Thel-vector recipient mice were injected with $0.1 \mu \mathrm{g}$ pCI-neo-H- $2 \mathrm{~K}^{\mathrm{d}}+0.6 \mu \mathrm{g}$ empty pCI-neo vectors $+1.4 \mu 1$ lipofectin (diluted with DMEM up to $70 \mu \mathrm{l}$ ). The 7 -vector recipient mice were injected with 


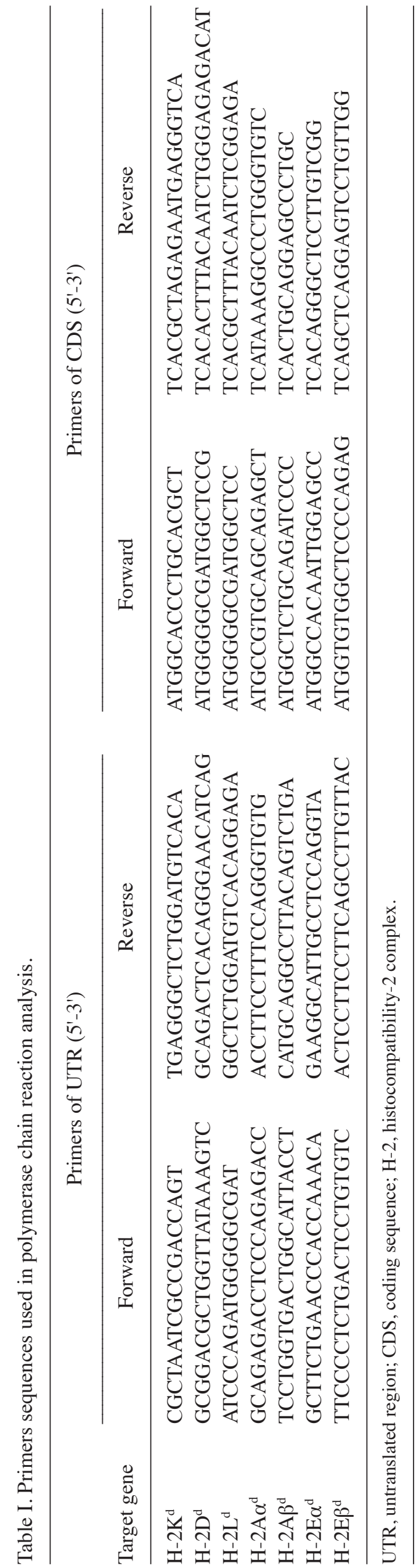

$0.1 \mu \mathrm{g}$ pCI-neo-H-2 $\mathrm{K}^{\mathrm{d}}+0.1 \mu \mathrm{g}$ pCI-neo-H-2D $\mathrm{D}^{\mathrm{d}}+0.1 \mu \mathrm{g}$ pCI-neo-H-2L ${ }^{\mathrm{d}}+0.1 \mu \mathrm{g}$ pCI-neo-H-2 $\mathrm{A}^{\mathrm{d}}+0.1 \mu \mathrm{g}$ pCI-neo-H-2A $\beta^{\mathrm{d}}+0.1 \mu \mathrm{g}$ pCI-neo-H-2E $\alpha^{\mathrm{d}}+0.1 \mu \mathrm{g}$ pCI-neo-H-2E $\beta^{\mathrm{d}}+1.4 \mu \mathrm{l}$ lipofectin (diluted with DMEM up to $70 \mu \mathrm{l})$. Recipient rats of the 1-vector experimental group were injected with $0.7 \mu \mathrm{g}$ pCI-neo-H-2 $\mathrm{K}^{\mathrm{d}}+1.4 \mu \mathrm{l}$ lipofectin (diluted by DMEM up to $70 \mu 1$ ).

Heart transplantations were performed immediately following the injections using the ear-back heart transplantation model $(18,19)$. The donor hearts were then excised and placed into the back of each recipient's right ear (Fig. 1E-H).

Electrocardiography and histology. All recipients had electrocardiographs (ECGs) every 2 days after transplantation until the ECG signal disappeared. When the ECG signal disappeared the recipient mice and rats were sacrificed. The transplanted hearts were removed, cut into slices and fixed in $10 \%$ formalin for $24 \mathrm{~h}$ at room temperature. Standard histological techniques were followed and the paraffin embedded samples were cut into $4-\mu \mathrm{m}$-thick sections. Following dewaxing the sections were stained using a standard hematoxylin and eosin staining method (hematoxylin for $3 \mathrm{~min}$ and eosin for 2-3 $\mathrm{min}$ at room temperature) and observed using a light microscope at magnification, $\mathrm{x} 100, \mathrm{x} 200$ and $\times 400$. Survival time of the transplanted heart was calculated as the mean number of days between the day of transplantation and the day when the ECG signal disappeared. The absence of an electrocardiosignal on days 2 and 4 indicated failure of transplant surgery, and the animal would be excluded from the group.

Transferred gene expression tests and mixed lymphocyte culture $(M L C)$ tests. Following the disappearance of the electrocardiosignal, the thymi of all recipients were removed and ground with a rubber stick to disperse the cells. The dispersed cells $\left(5 \times 10^{6}-1 \times 10^{7} / \mathrm{ml}\right)$ were blocked with $1 \%$ bovine serum albumin (Sigma-Aldrich; Merck KGaA) at $37^{\circ} \mathrm{C}$ for $4 \mathrm{~h}$, incubated with primary anti-H-2-K and anti-H-2-D antibodies (as above; 1:100 dilution) and normal rabbit serum (Sigma-Aldrich; Merck KGaA) at $4^{\circ} \mathrm{C}$ for $30 \mathrm{~min}$. The cells were then washed with PBS and incubated with fluorescein isothiocyanate-conjugated secondary goat-anti-mouse antibodies (cat. no. 115-005-003; 1:200 dilution; Jackson ImmunoResearch, West Grove, PA, USA) at $4^{\circ} \mathrm{C}$ for $30 \mathrm{~min}$ and then subjected to flow cytometry using a flow cytometer with FlowJo 7.6.1 software (FlowJo LLC.; BD Biosciences, Franklin Lakes, NJ, USA).

Reverse transcription-PCR analyses were performed in the three mouse recipient groups as previously performed in the second PCR step. The CDS primers used in the second PCR step of the gene preparation phase (Table I) were also used to examine the expression of the seven transferred loci in recipients.

The histocompatibility between donors and recipients was assessed using an MLC kit (Tiangen Biotech Co., Ltd.). The spleens of the recipients and the donors were removed and ground with a rubber stick to disperse the cells. They were subsequently cultured in RPMI 1640 medium supplemented with $10 \%(\mathrm{v} / \mathrm{v})$ heat-inactivated fetal bovine serum (both Gibco; Thermo Fisher Scientific, Inc.) in $5 \% \mathrm{CO}_{2}$ at $37^{\circ} \mathrm{C}$. Spleen cells collected from the control, 1-vector and 7-vector 

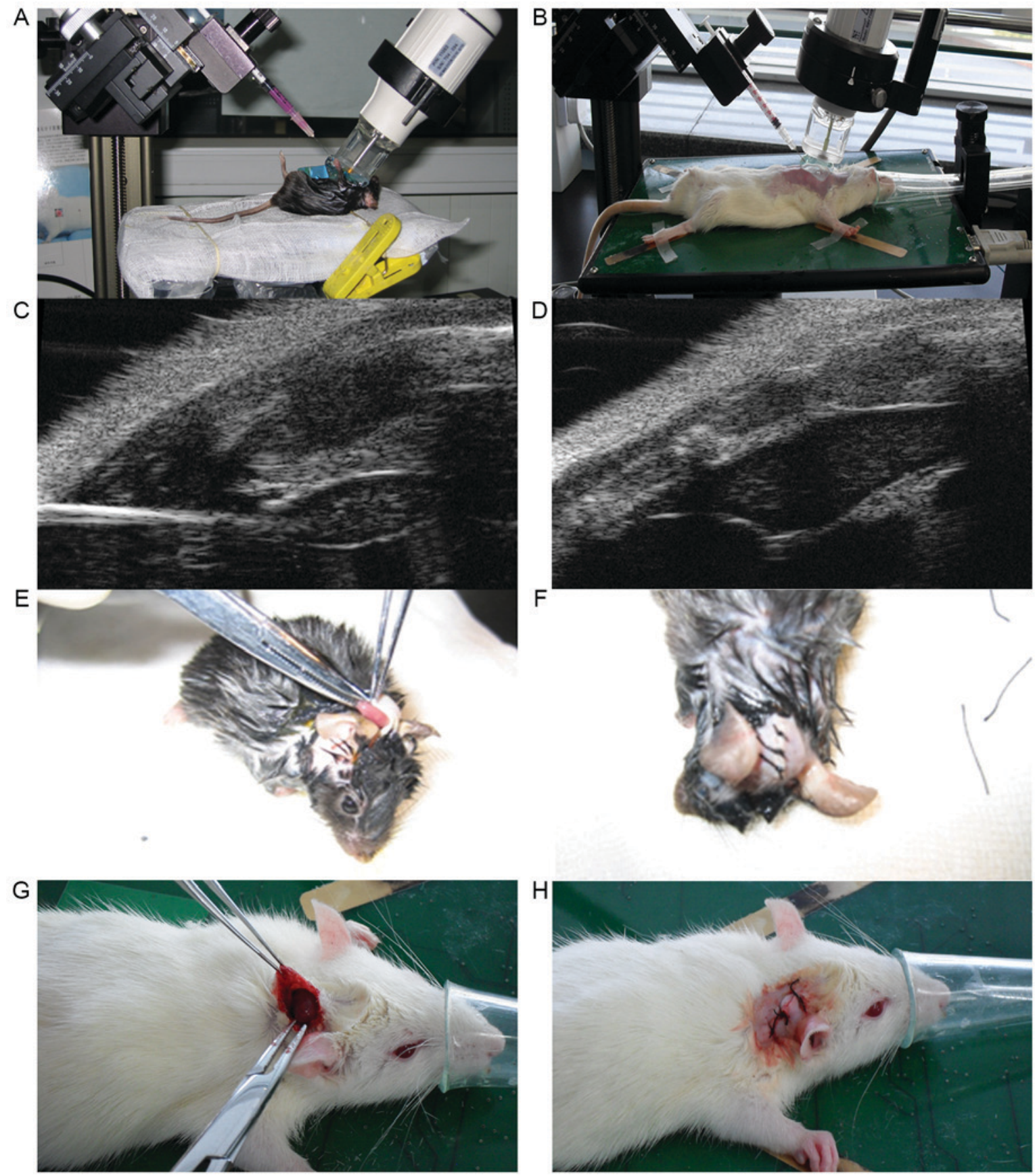

Figure 1. Preparation for injection of vector containing loci of MHC class I and II donor mouse genes or empty vector. The mice and rats stopped moving following anesthesia, but their eyes usually remained open. The thymi of (A) mice and (B) rats were punctured. Ultrasound image showing (C) the needle near the thymus and (D) an opaque dark area of fluid that formed following injection. (E and F) The mouse donor's heart was transplanted into the mouse recipient. $(\mathrm{G}$ and $\mathrm{H})$ The mouse donor's heart was transplanted into the rat recipient.

mice, and the control and 1-vector rats were mixed with the spleen cells from the donors' strain or the spleen cells from a third strain from mice at the UK Institute of Cancer Research (London, UK; ICR) respectively, and cultured in RPMI 1640 medium supplemented with $10 \%(\mathrm{v} / \mathrm{v})$ heat-inactivated fetal bovine serum in $5 \% \mathrm{CO}_{2}$ at $37^{\circ} \mathrm{C}$ for $24 \mathrm{~h}$. Cell density was then measured using the MTT method. The purple formazan crystals were dissolved by dimethyl sulfoxide at a wavelength of $570 \mathrm{~nm}$.

Statistical analysis. Statistical analysis was performed with SPSS 21.0 (IBM Corp., Armonk, NY, USA). A minimum of three repeats were performed for each experiment. The data are presented as the mean \pm standard deviation. Differences between multiple groups were analyzed using one-way analysis of variance followed by the Newman-Keuls test. Differences between two groups were analyzed using the paired-samples t-test. $\mathrm{P}<0.05$ was considered to indicate a statistically significant difference.

\section{Results}

Donor's seven loci of the $\mathrm{H}-2^{d}$ genes were obtained. Electrophoresis was performed following the first PCR step of nested PCR and revealed a $\beta$-actin (internal reference) band, 
A

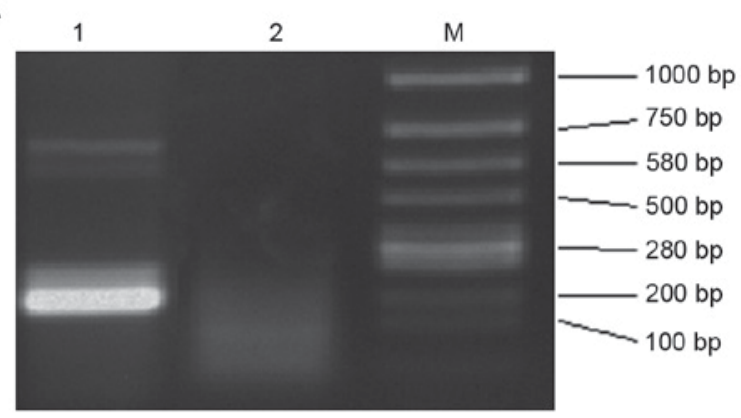

C

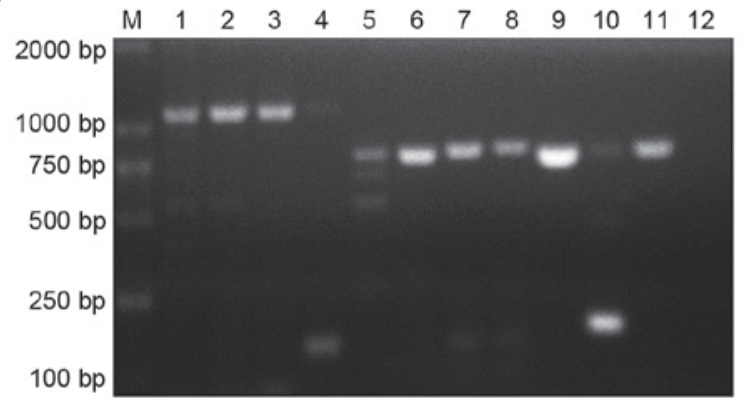

B
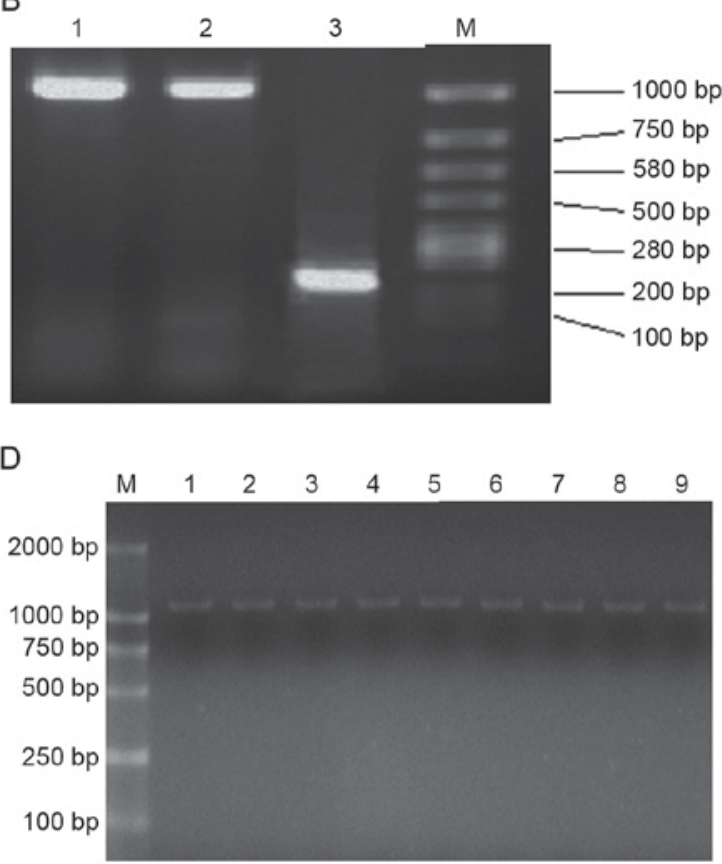

E

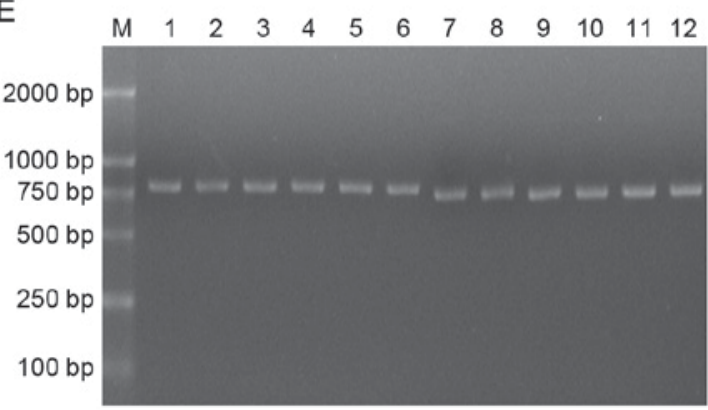

Figure 2. Donor loci of the H-2 ${ }^{\mathrm{d}}$ genes were obtained and expression vectors were constructed. (A) The first PCR step electro-blottings were indicated. Lane 1, $\beta$-actin; lane 2, the product of PCR; M, marker. (B) The second PCR step electro-blottings were indicated. Lane 1, the PCR product of K ${ }^{\mathrm{d}}$ locus by pfu MasterMix; lane 2, product by Tap Platinum PCR MasterMix; lane 3, $\beta$-actin; M, marker. (C) The second PCR step electro-blottings were indicated. M, marker; lane 1, D locus by pfu MasterMix; lane 2, $\mathrm{D}^{\mathrm{d}}$ locus by Tap Platinum PCR MasterMix; lane 3, $\mathrm{L}^{\mathrm{d}}$ locus by pfu MasterMix; lane 4, L locus by Tap Platinum PCR MasterMix; lane 5, A $\alpha^{\mathrm{d}}$ locus by pfu MasterMix; lane 6, A $\alpha^{\mathrm{d}}$ locus by Tap Platinum PCR MasterMix; lane 7, A $\beta^{\mathrm{d}}$ locus by pfu MasterMix; lane 8, A $\beta^{\mathrm{d}}$ locus by Tap Platinum PCR MasterMix; lane 9, E $\alpha^{\mathrm{d}}$ locus by pfu MasterMix; lane 10, E $\alpha^{\mathrm{d}}$ locus by Tap Platinum PCR MasterMix; lane 11, E $\beta^{\mathrm{d}}$ locus by pfu MasterMix; lane 12, E $\beta^{\mathrm{d}}$ locus by Tap Platinum PCR MasterMix. (D) Electro-blottings of PCR results for pCI-neo-H-2 ${ }^{\mathrm{d}}$ clones were indicated. M, marker; lanes 1-3, three blottings of pCI-neo-K ${ }^{\mathrm{d}}$; lanes 4-6,three blottings of pCI-neo-D ${ }^{\mathrm{d}}$; lanes 7-9, three blottings of pCI-neo-L ${ }^{\mathrm{d}}$. (E) Electro-blottings of PCR results for pCI-neo-H-2 ${ }^{\mathrm{d}}$ clones. $\mathrm{M}$, marker; lanes 1-3, three blottings of pCI-neo-A $\alpha^{\mathrm{d}}$; lanes $4-6$, three blottings of pCI-neo-A $\beta^{\mathrm{d}}$; lanes 7-9, three blottings of pCI-neo-E $\alpha^{\mathrm{d}}$; lanes 10-12, three clones of pCI-neo-E $\beta^{\mathrm{d}}$. PCR, polymerase chain reaction; H-2, histocompatibility-2 complex.

indicating successful extraction of total RNA and reverse transcription (Fig. 2A). However, as expected, no product band was detectable. Electrophoresis following the second PCR step yielded bands that sequence analysis confirmed were the seven loci (in accordance with the GenBank accession nos. NW001030614.1, M18523, M33151, AY452201, AY452202, K00971 and NT039662.2) of the H-2 ${ }^{\mathrm{d}}$ genes: H-2K ${ }^{\mathrm{d}}, \mathrm{H}-2 \mathrm{D}^{\mathrm{d}}$, H-2L ${ }^{\mathrm{d}}, \mathrm{H}-2 \mathrm{~A} \alpha^{\mathrm{d}}, \mathrm{H}-2 \mathrm{~A} \beta^{\mathrm{d}}, \mathrm{H}-2 \mathrm{E} \alpha^{\mathrm{d}}$ and H-2E $\beta^{\mathrm{d}}$ (Fig. 2B and C). The yield obtained with pfu MasterMix was larger and clearer than that obtained with Tap Platinum Mastermix, therefore pfu MasterMix was use to retrieve $\mathrm{H}-2^{\mathrm{d}}$ genes in subsequent experiments.

Mammalian expression vectors were constructed. Electrophoresis of PCR results of pCI-neo-H- $2^{\mathrm{d}}$ clones yielded clear bands, demonstrating that the construction of mammalian expression vector was successful (Fig. 2D and E). The nested PCR protocol required two PCR steps; due to this the likelihood of base mismatches was greater than in simpler protocols. Upon digestion of $\mathrm{pBS}-\mathrm{T}-\mathrm{H}-2^{\mathrm{d}} \mathrm{s}$ and ligation of the seven loci of $\mathrm{H}-2^{\mathrm{d}}$ genes into pCI-neo to generate pCI-H- $2^{\mathrm{d}} \mathrm{s}$, sequence analysis revealed that the plasmid in every colony had identical apparent mismatches. Clones containing base mismatches that had no effect on the amino acid sequence were selected to transfer donor vectors into the recipient thymi.

Prolonged ECG signals were indicated in transgene recipients following heart transplantation. One mouse in the control group succumbed to fatality during the thymus injection and 1 mouse in the 1-vector group succumbed during the heart transplantation. A total of 5 mice succumbed on 1 or 2 days after transplantation ( 3 in the control group, 1 in the 1 -vector group and 1 in the 7-vector group). No rats succumbed to fatality during the injection or following 
A
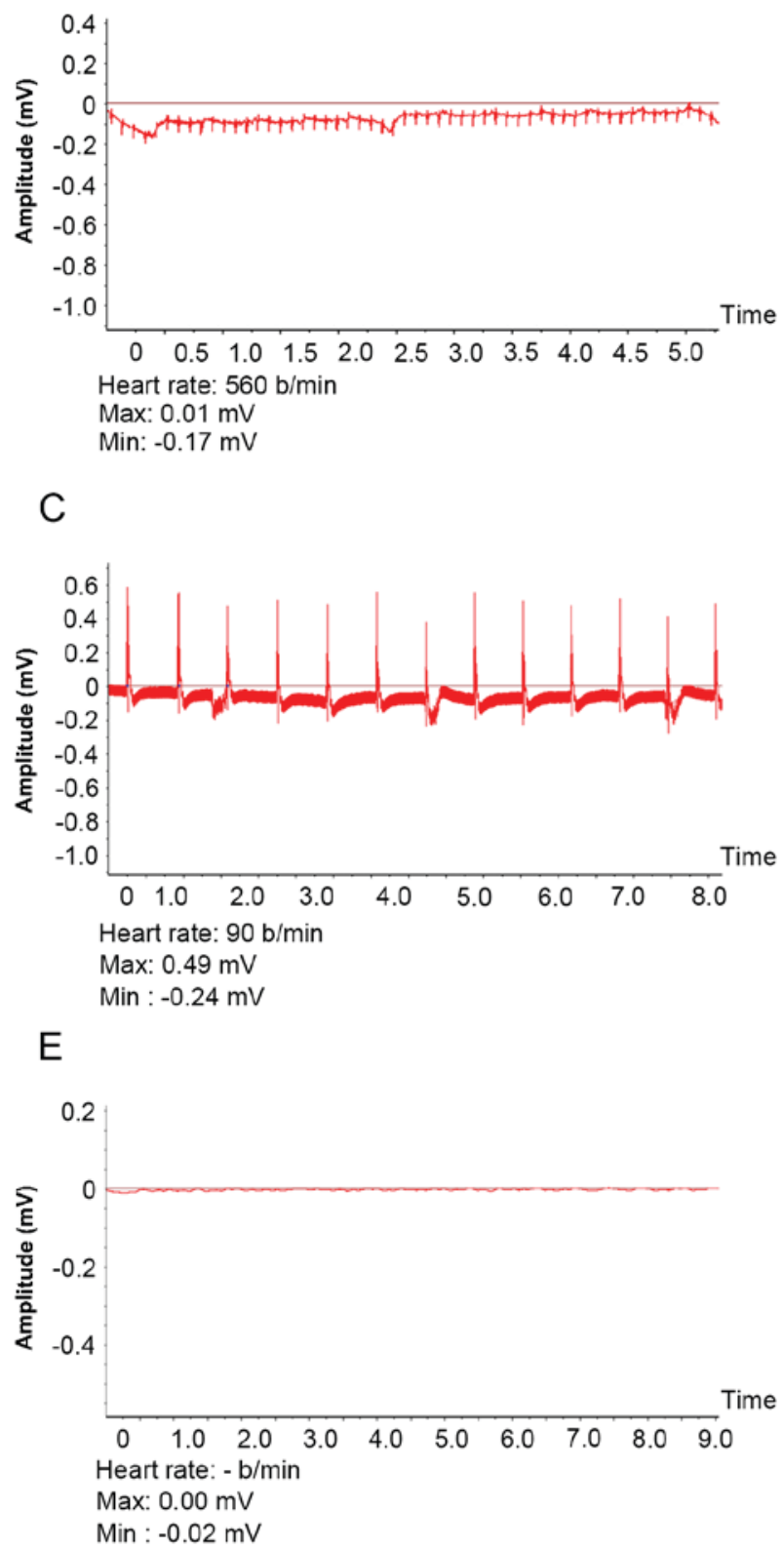

B
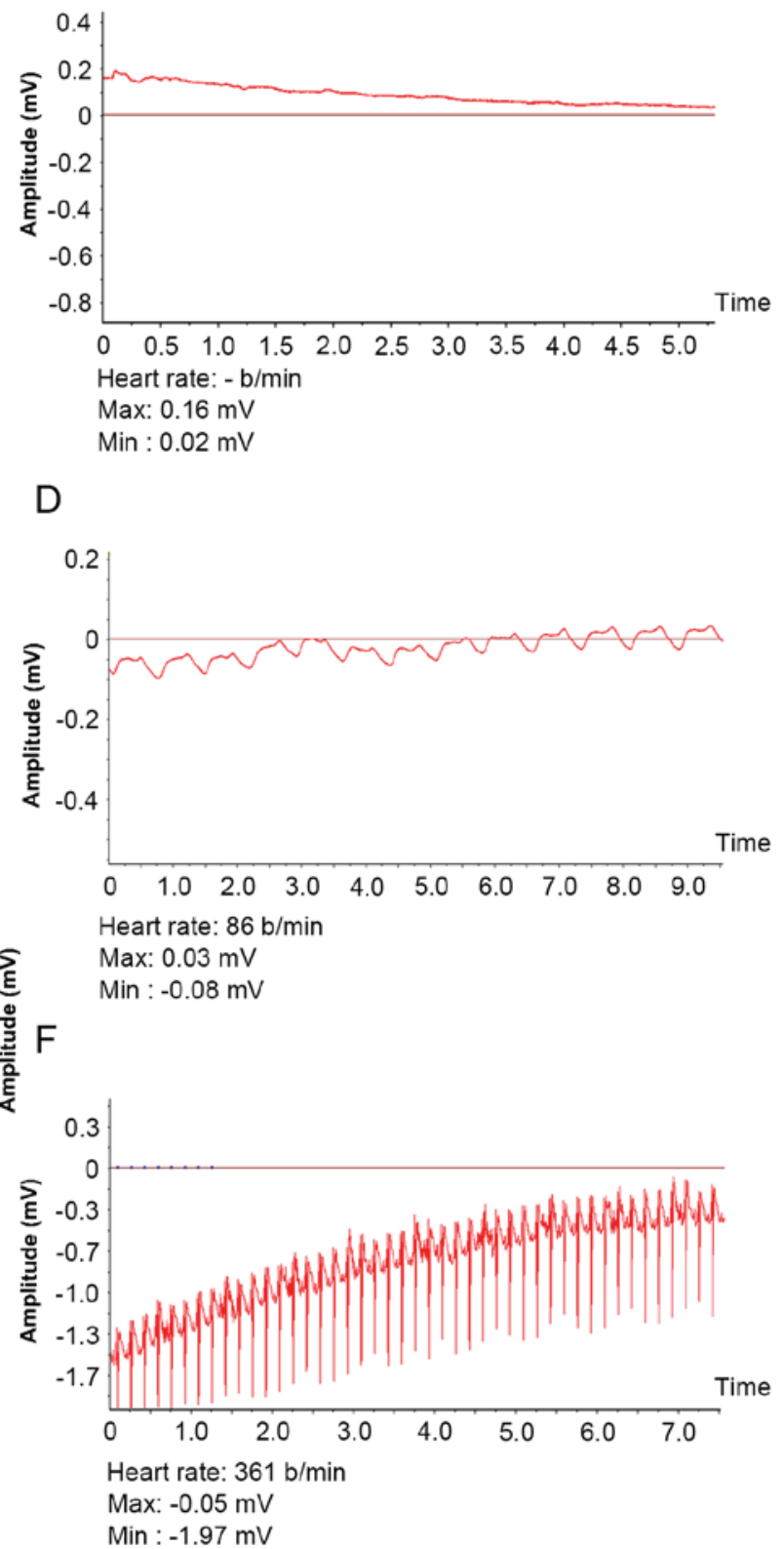

Figure 3. ECG signals were prolonged in transgene recipients following heart transplantation. (A) The ECG wave of the transplanted heart in a representative mouse recipient was indicated. (B) The ECG wave of the transplanted heart in a mouse recipient disappeared 16 days after transplantation. (C) The normal ECG wave in a mouse and (D) the ECG wave of the transplanted heart in a rat recipient were indicated. (E) The ECG wave of the transplanted heart in a rat recipient disappeared 11 days after transplantation. (F) The normal ECG wave in a rat was indicated. ECG, electrocardiograph.

transplant. On days 2 and 4 after transplantation, no electrocardiosignal was detected in 11-vector mouse, 11-vector rat and 1 control mouse. Electrocardiosignals (Fig. 3) were detected for a significantly longer duration in the 7 -vector mouse group $(23.59 \pm 6.70$ days $)$ compared with the 1 -vector $(16.67 \pm 6.6$ days; $\mathrm{P}<0.05)$ or control mouse group $(9.11 \pm 2.75$ days; $\mathrm{P}<0.01)$. In rats, electrocardiosignals were significantly longer in 1 -vector rats compared with the control rate $(14.61 \pm 2.98$ vs. $6.40 \pm 1.58$ days; $\mathrm{P}<0.01)$.

Expression of donor $\mathrm{H}-2^{d}$ genes in recipient thymi. Following the disappearance of the ECG signal, the thymi of the recipients were removed and subjected to flow cytometry and PCR analysis. In the 1-vector mice, the positive ratio of $\mathrm{H}-2 \mathrm{~K}^{\mathrm{d}}$ was
$36.83 \pm 8.96 \%$ and $\mathrm{H}-2 \mathrm{D}^{\mathrm{d}}$ was negative (Fig. $4 \mathrm{~A}$ and $\mathrm{B}$ ). In the 7-vector mice, the positive ratio of $\mathrm{H}-2 \mathrm{~K}^{\mathrm{d}}$ was $43.61 \pm 6.35 \%$ and that of $\mathrm{H}-2 \mathrm{D}^{\mathrm{d}}$ was $50.08 \pm 7.21 \%$ (Fig. $4 \mathrm{C}$ and D). In 1-vector rats, the positive ratio of $\mathrm{H}-2 \mathrm{~K}^{\mathrm{d}}$ was $60.69 \pm 1.06 \%$ (Fig. 4E). H-2 $\mathrm{K}^{\mathrm{d}}$ and $\mathrm{H}-2 \mathrm{D}^{\mathrm{d}}$ were negative in control mice and $\mathrm{H}-2 \mathrm{~K}^{\mathrm{d}}$ was negative in control rats (data not shown). Electrophoresis following PCR yielded bands of $\mathrm{H}-2 \mathrm{~K}^{\mathrm{d}}$ in 1-vector mice (Fig. 4F) and seven loci of the $\mathrm{H}-2^{\mathrm{d}}$ genes in 7-vector mice (Fig. 4G). There was no $\mathrm{H}-2^{\mathrm{d}}$ band in control mice (data not shown). Mouse $\beta$-actin mRNA bands appeared in the three mouse groups. Taken together, the flow cytometry and PCR results indicate that the $\mathrm{H}-2^{\mathrm{d}}$ genes were transferred into and expressed in the mouse and rat recipients' thymus stromal cells. 
A

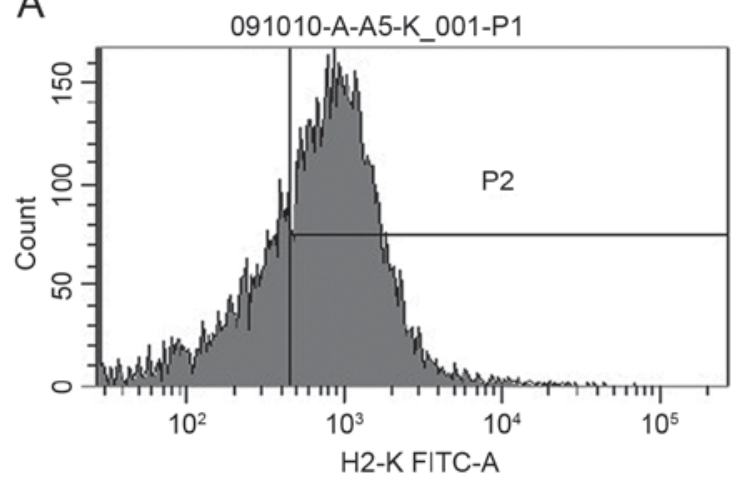

C

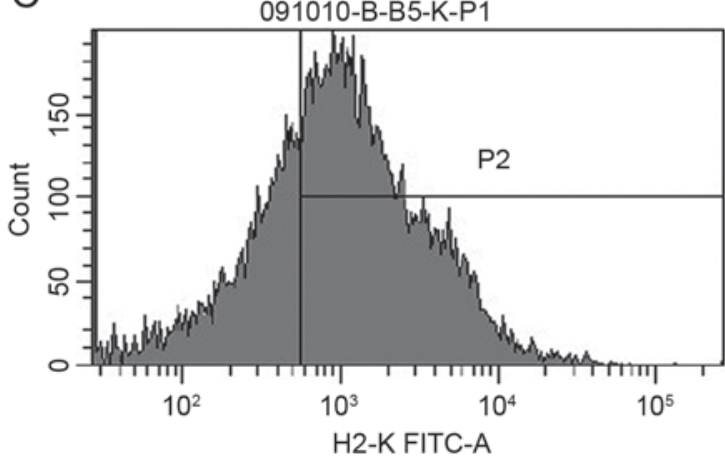

$\mathrm{B}$

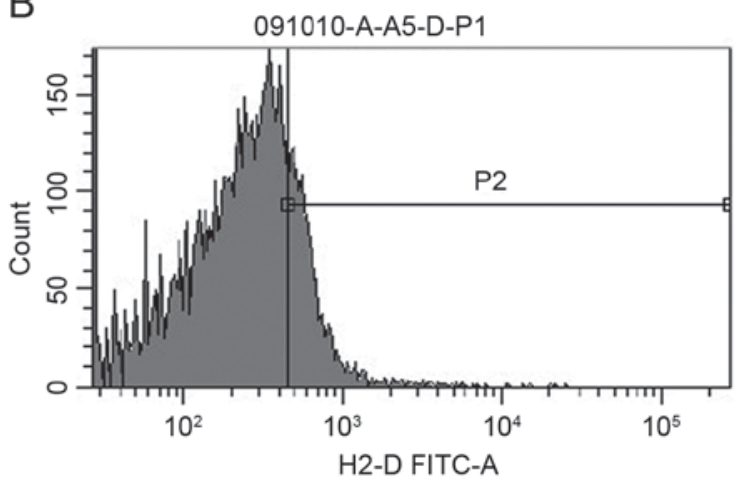

D

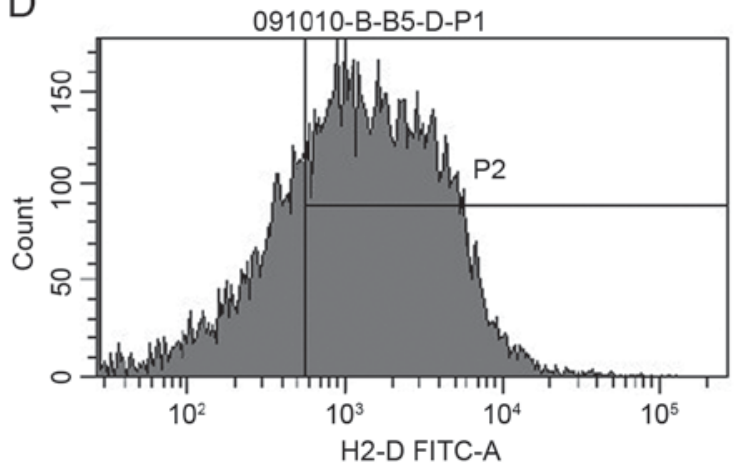

$\mathrm{E}$ 091010-DS-DS2-K-P1

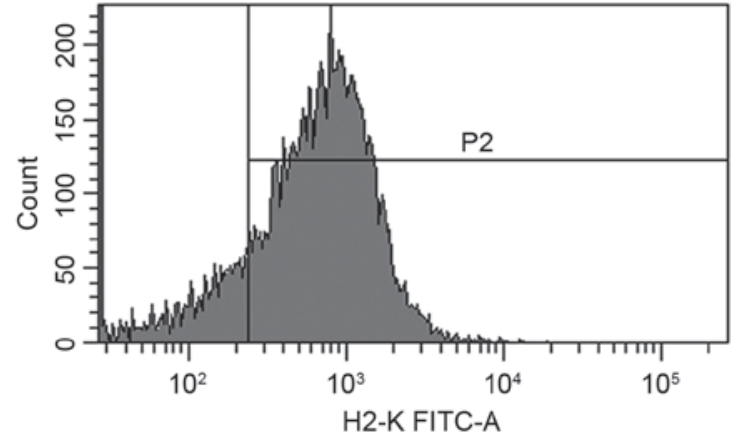

$\mathrm{F}$

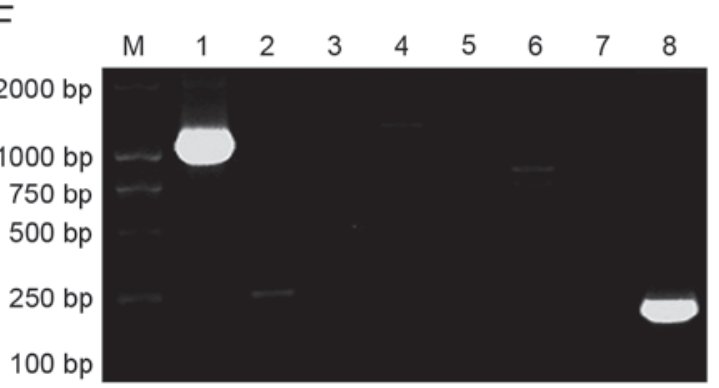

$\mathrm{G}$

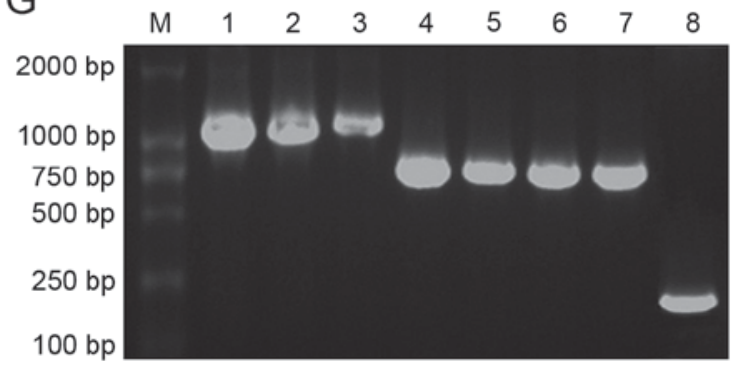

Figure 4. Donor H-2 ${ }^{\mathrm{d}}$ genes express in recipient thymi. Flow cytometry results of the 1-vector mice (A) incubated with anti-mouse H-2K $\mathrm{K}^{\mathrm{d}}$ antibodies and (B) anti-mouse H-2D ${ }^{d}$ antibodies were determined. Flow cytometry results of the 7-vector mice (C) incubated with anti-mouse H-2K $\mathrm{K}^{\mathrm{d}}$ antibodies and (D) incubated with anti-mouse $\mathrm{H}-2 \mathrm{D}^{\mathrm{d}}$ antibodies were also indicated. (E) Flow cytometry results of the experimental (1-vector) rats incubated with anti-mouse H-2K antibodies were indicated. PCR results of the thymus cells from (F) 1-vector recipient mice (the bands of $\mathrm{H}-2 \mathrm{~K}^{\mathrm{d}}$ and mouse $\beta$-actin are clear) and (G) 7 -vector recipient mice (all the bands of seven $\mathrm{H}-2^{\mathrm{d}}$ loci and mouse $\beta$-actin are clear) were obtained. PCR, polymerase chain reaction; $\mathrm{H}-2$, histocompatibility-2 complex. Lane 1, H-2K $\mathrm{K}^{\mathrm{d}}$; lane $2, \mathrm{H}-2 \mathrm{D}^{\mathrm{d}}$; lane $3, \mathrm{H}-2 \mathrm{~L}^{\mathrm{d}}$; lane $4, \mathrm{H}-2 \mathrm{~A} \alpha^{\mathrm{d}}$; lane $5, \mathrm{H}-2 \mathrm{~A} \beta^{\mathrm{d}}$; lane $6, \mathrm{H}-2 \mathrm{E} \alpha^{\mathrm{d}}$; lane $7, \mathrm{H}-2 \mathrm{E} \beta^{\mathrm{d}}$ and lane 8 , $\beta$-actin.

Histological analysis demonstrated that the transgene recipients were healthy. Histological analysis of sections of transplanted hearts revealed that the skin around the heart was clearly edematous in control mice and rats; edema was reduced in the experimental groups (Fig. 5). Control hearts demonstrated marked lymphocyte infiltration, disruption of the characteristic intracellular structure of the cardiomyocytes and cell necrosis (Fig. 5A and D). By contrast, experimental hearts in the two species demonstrated minor lymphocyte infiltration and the intracellular structure of the cardiomyocytes was retained (Fig. 5B, C and E). These characteristics differed little between the 1-vector mice and the 7-vector mice. These results 

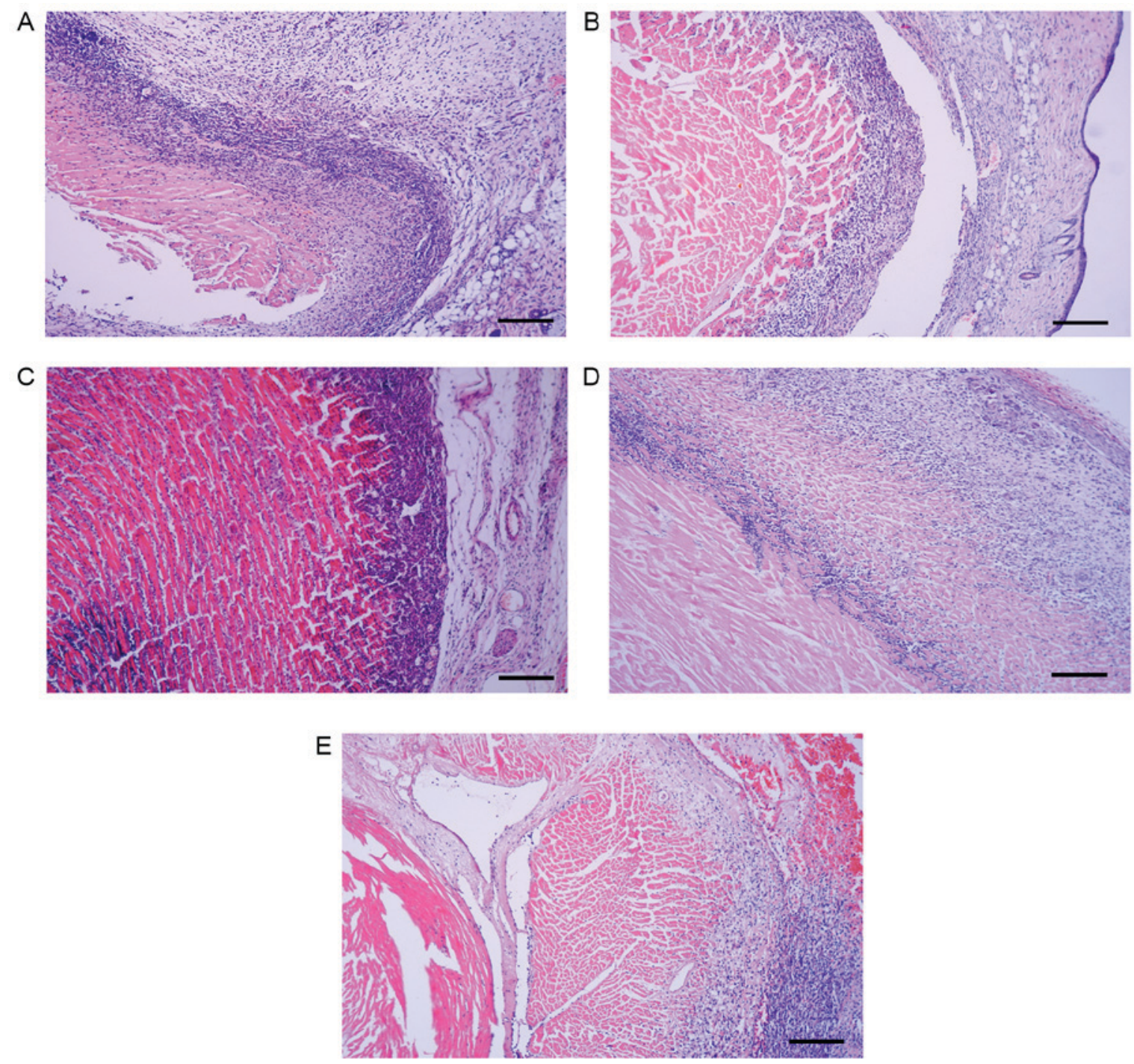

Figure 5. Histological analysis of sections of transplanted hearts. Histological sections of hearts transplanted into (A) control (B) 1-vector and (C) 7-vector mice, and (D) control and (E) experimental (1-vector) rats were demonstrated. Scale bar, $50 \mu \mathrm{m}$.

indicate that the rejection was reduced in the transgene recipients compared with the control recipients in mice and rats.

High histocompatibility in transgene recipients. The results of MLC tests are summarized in Table II. Mixtures of spleen cells from donor mice, recipient mice and recipient rats were cultured and assessed. The cell density was significantly greater among cells in the control groups compared with the experimental groups $(\mathrm{P}<0.01$; Table II), indicating greater histocompatibility in the latter. Cell density was significantly greater in 1-vector mice compared with 7-vector mice $(\mathrm{P}<0.05)$, indicating higher histocompatibility in the latter. The density in the cells from the control and experimental groups did not significantly differ when they were separately mixed with cells from a third strain (ICR). As expected, cell densities were significantly higher when the recipient cells from the experimental groups were mixed with ICR cells (all $\mathrm{P}<0.01)$ compared with when they were mixed with donor cells. These results indicate that the histocompatibility with donor cells is higher in transgene recipients compared with control recipients.

\section{Discussion}

In the present study, to determine whether a donor's MHC could be introduced into and expressed in a recipient's thymus, tolerance to transplantation was assessed. It was assumed that transferring all seven loci of donor's MHC I and II genes would be more effective than transferring only the $\mathrm{K}$ locus. The results of the present study demonstrated that transplanted hearts survived significantly longer in mice in which seven loci were transferred compared with that in mice in which only the $\mathrm{K}$ locus was transferred $(23.59 \pm 6.70$ vs. $16.67 \pm 6.6$ days; $\mathrm{P}<0.05)$. In addition, transplanted hearts in the two experimental mouse groups survived significantly longer compared with those in control mice $(9.11 \pm 2.75$ days; both $\mathrm{P}<0.01)$. Furthermore, the heterograft transplantation effect was observed by transferring the $\mathrm{K}$ locus of the $\mathrm{H}-2^{\mathrm{d}}$ genes from donor mice into recipient rats and by transplanting mice hearts into rats. Once again, the transplanted hearts survived longer in the experimental group compared with the control rats $(\mathrm{P}<0.01)$. This result suggests that transferring a donor's MHC gene into a recipient may also be effective in heterografts. 
Table II. Histocompatibility between donors and recipients.

\begin{tabular}{lccc}
\hline Group & $\begin{array}{c}\text { Mixed spleen cells from } \\
\text { recipients and donors }\end{array}$ & $\begin{array}{c}\text { Mixed spleen cells from } \\
\text { recipients and ICR }\end{array}$ & $\begin{array}{c}\text { Paired-samples } \\
\text { T test results }\end{array}$ \\
\hline Control mice $(\mathrm{n}=10)$ & $0.446 \pm 0.021$ & $0.442 \pm 0.016$ & $\mathrm{t}=0.479, \mathrm{P}>0.05$ \\
1-vector mice $(\mathrm{n}=12)$ & $0.383 \pm 0.015^{\mathrm{a}}$ & $0.424 \pm 0.018$ & $\mathrm{t}=6.062, \mathrm{P}<0.01$ \\
7-vector mice $(\mathrm{n}=14)$ & $0.362 \pm 0.021^{\mathrm{b}}$ & $0.421 \pm 0.021$ & $\mathrm{t}=7.433, \mathrm{P}<0.01$ \\
Control rats $(\mathrm{n}=10)$ & $0.204 \pm 0.058$ & $0.218 \pm 0.033$ & $\mathrm{t}=0.663, \mathrm{P}>0.05$ \\
1-vector rats $(\mathrm{n}=9)$ & $0.102 \pm 0.029$ & $0.213 \pm 0.045$ & $\mathrm{t}=6.220, \mathrm{P}<0.01$ \\
\hline
\end{tabular}

${ }^{\mathrm{a}} \mathrm{P}<0.01 \mathrm{vs}$. control mice in the mixed spleen cells from recipient and donors group. ${ }^{\mathrm{b}} \mathrm{P}<0.05 \mathrm{vs}$. 1 -vector mice in the spleen cells from mixed recipient and donors group. Histocompatibility between donors and recipients was assessed using mixed lymphocyte culture tests. Spleen cells collected from recipients were mixed with spleen cells from donors and the strain from the ICR. ICR, Institute of Cancer Research.

Although prior introduction of a donor's MHC antigen, cells or tissue into the recipient has been revealed to delay allograft rejection (20-23), the finding that intravenous administration of a donor's MHC antigen to a recipient does not suppress rejection (24) suggests the allograft may ultimately be rejected. Consistent with that theory, when Gopinathan et al (25) intravenously injected dendritic cells from a donor rat into a recipient, the cells did not home into the lymph nodes, bone marrow or thymus, and so would not be expected to have a meaningful impact on rejection. Additionally, Hillebrands et al (26) revealed that introduction of donor splenic cells into a recipient thymus prior to transplantation prolonged survival time somewhat; however, they noted that chronic rejection could not be suppressed. Similarly, Kobayashi et al (27) reported that injecting donor cells into a recipient's thymus did not induce tolerance. Trani et al (28) suggested that T cell clonal frequency reduction and transplantation tolerance induced by intrathymic alloantigen inoculation was incomplete and transient.

Certain studies have demonstrated that transfecting a donor's MHC into cells from a recipient and then returning the transfectants to the recipient did mitigate rejection $(29,30)$. This approach was used in a previous study by our group. One locus of a donor's MHC genes was introduced into the recipient thymus stromal cell in vitro and these transfected cells were subsequently injected back into the thymus of the recipient prior to transplantation. The results revealed that the survival time of transplanted hearts prolonged (17). However, a limitation of this approach would be that it may take a prolonged period of time to select cell clones that express the loci of donor MHC. On the other hand, several studies have reported the beneficial effects of introducing a plasmid harboring one locus of a donor's MHC into a recipient $(29,31,32)$. Therefore, the plasmids of seven loci were introduced to the recipients thymi directly in the present study.

The function of the thymus in immunity and following transplantation has been well studied (33-37), although the findings are somewhat conflicting. When thymus tissue from a donor was embedded in a renal vesicle to form a composite thymokidney, which was then transplanted into the recipient, rejection was mitigated $(36,37)$. The results from Viret et al (38) are most consistent with a model where, in addition to the thymocyte/stromal cell interaction avidity, negative selection is largely determined by accessibility to self-determinants, regardless of their anatomical distribution in the thymus. The involvement of multiple stromal cell types in negative selection may assist in minimizing the chances of autoreactive $\mathrm{T}$ cell escape. In that context, the plasmids of seven loci of donor $\mathrm{H}-2^{\mathrm{d}}$ genes were introduced into the recipient's thymus to induce the deletion of $\mathrm{T}$ cells that could react with the donor's H-2 antigen during negative selection.

Typically a $2 \mu \mathrm{g}$ sample of total RNA is used to amplify a given target gene, but as levels of $\mathrm{H}-2$ mRNA of these seven loci were very low, amplification required a larger amount of total RNA (39) or the amount produced would be insufficient. This obstacle was overcome by using two-step nested PCR as amplifying the RNA twice produced an increased total amount. The results demonstrated that the amount produced by the first PCR were too small to visualize the electrophoresis bands. However the amount productions by the second PCR was sufficient and the electrophoresis bands were observed clearly.

In the present study, plasmids containing the donor's MHC were injected into the recipient's thymus. By visualizing the procedure using ultrasound, the depth and position of the injection site was precisely determined. The wounds were not serious; the mortality rate was $0 \%$ in rats and $2.2 \%$ in mice. Although thymus injection under ultrasound guidance in animal experiments has not, to the best of our knowledge, been previously reported, the experiences during the current study suggests it is effective and useful.

In previous studies, transplantation was performed 1-2 weeks after a donor gene, antigen or donor cells were introduced into the recipient (40-42). The aim of the present study was to develop a more clinically relevant technique by introducing the donor gene and transplanting the donor hearts on the same day. In the present study, negative selection, which is a process by which T cells that react with self-MHC antigen are removed through apoptosis, did not happen immediately and it was hypothesized that this may explain the shorter survival time of transplanted organs in the current study compared with other reports (40-42). However, the results of the present study were positive overall, suggesting that the negative selection did work. The positive results suggest that introducing the donor's MHC into the recipient's thymus may be beneficial, as no immunosuppressants were used in these experiments but the rejection was mitigated. The MLC tests performed in the present study demonstrated that the recipient's cells had 
less reaction with the donor's cells in experimental groups compared with that in control groups. These results suggested a better compatibility between the recipient and donor tissue and less rejection in the experimental groups.

Overall, the findings suggested that the expression of the donor gene and the resultant negative selection of $\mathrm{T}$ cells was sufficient. That is, transfer of the donor MHC (H-2) to the recipient enabled the recipient, at some level, to recognize the donor's tissue as self, thereby mitigating rejection.

In conclusion, the long existence of the electrocardiosignal in the experimental groups, histological analysis and other results of the present study suggest that rejection of transplanted hearts may be mitigated substantially by introducing the donor's MHC into the recipient, however further studies are warranted.

\section{Acknowledgements}

The authors would like to thank Dr. Yueping Lv (preclinical medical lab, Beijing Chao-Yang Hospital, Capital Medical University, Beijing, China) for his important directions in PCR. The authors would also like to thank Miss Pamela Derish (Department of Surgery, UCSF, San Francisco, CA, USA) for editorial assistance with the current study.

\section{Funding}

No funding was received.

\section{Availability of data and materials}

The datasets used and/or analyzed during the current study are available from the corresponding author on reasonable request.

\section{Authors' contributions}

TL, WZ, DMJ, SL and LY conceived and designed the experiments. WZ, TL, XT, JD and QX performed the experiments. HL, ZX and SH analyzed the data. SL and XT contributed reagents/materials/analysis tools. TL, LY and WZ wrote the paper. LY, JD and ZX reviewed and revised the manuscript. DMJ and JD gave important directions to the study and revised the manuscript.

\section{Ethics approval and consent to participate}

All experiments were conducted in accordance with University of California, San Francisco Animal Care and Use requirements, and approved by the Capital University of Medical Science Institutional Animal Care and Use Committee (Beijing, China).

\section{Consent for publication}

Not applicable.

\section{Competing interests}

The authors declare that they have no competing interests.

\section{References}

1. Bharat A, Kuo E, Steward N, Aloush A, Hachem R, Trulock EP, Patterson GA, Meyers BF and Mohanakumar T: Immunological link between primary graft dysfunction and chronic lung allograft rejection. Ann Thorac Surg 86: 189-195, 2008.

2. Corris PA and Christie JD: Update in transplantation 2007. Am J Respir Crit Care Med 177: 1062-1067, 2008.

3. Pham VV, Stichtenoth DO and Borlak J: Graft rejection: Pharmacogenetic analysis or drug anamnesis? Br J Clin Pharmacol 65: 959-960, 2008.

4. Peeters P, Van Laecke S and Vanholder R: Acute kidney injury in solid organ transplant recipients. Acta Clin Belg 62 (Suppl 2): S389-S392, 2007.

5. Lechler RI, Sykes M, Thomson AW and Turka LA: Organ transplantation-how much of the promise has been realized? Nat Med 11: 605-613, 2005.

6. Kim JI, Sonawane SB, Lee MK, Lee SH, Duff PE, Moore DJ, O'Connor MR, Lian MM, Deng S, Choi Y, et al: Blockade of GITR-GITRL interaction maintains Treg function to prolong allograft survival. Eur J Immunol 40: 1369-1374, 2010.

7. Peugh WN, Superina RA, Wood KJ and Morris PJ: The role of $\mathrm{H}-2$ and non- $\mathrm{H}-2$ antigens and genes in the rejection of murine cardiac allografts. Immunogenetics 23: 30-37, 1986.

8. Wood KJ (ed): Principles of transplantation immunology. In: Oxford Textbook of Medicine. Oxford University Press, Oxford, p108, 2003.

9. Beck S and Trowsdale J: The human major histocompatability complex: Lessons from the DNA sequence. Annu Rev Genomics Hum Genet 1: 117-137, 2000.

10. Yu CL: Major histocompatibility complex (introduction). In: Modern Medical Immunology. Shanghai Medical University Publishing House, Shanghai, pp168-169, 1998.

11. Parmar S, Del Lima M, Zou Y, Patah PA, Liu P, Cano P, Rondon G, Pesoa S, de Padua Silva L, Qazilbash MH, et al: Donor-recipient mismatches in MHC class I chain-related gene $\mathrm{A}$ in unrelated donor transplantation lead to increased incidence of acute graft-versus-host disease. Blood 114: 2884-2887, 2009.

12. Fang $M$ and Shen GX: The differentiation of T cell. In: Medical Immunology. Gong FL(ed) Science Publishing House, Beijing, pp151-153,2000.

13. Maurice D, Hooper J, Lang G and Weston K: c-Myb regulates lineage choice in developing thymocytes via its target gene Gata3. EMBO J 26: 3629-3640, 2007.

14. Goldrath AW and Bevan MJ: Selecting and maintaining a diverse T-cell repertoire. Nature 402: 255-262, 1999.

15. Kishimoto $\mathrm{H}$ and Sprent J: The thymus and central tolerance. Clin Immunol 95: S3-S7, 2000.

16. Kruskall MS: The major histocompatibility complex: The value of extended haplotypes in the analysis of associated immune diseases and disorders. Yale J Biol Med 63: 477-486, 1990.

17. Li T, Yan J, Tan JL, Lv YP, Hou SC, Li ST, Xu Q, Tong XH, Ding J, Zhang Zt and Li H: Donor MHC gene to mitigate rejection of transplantation in recipient mice. Chin Med J (Engl) 124: 4279-4285, 2011.

18. Judd KP and Trentin JJ: Cardiac transplantation in mice. Transplantation 11: 298-308, 1971.

19. Babang G, Morris RE, Babang I and Kates RE: Evaluation of the in vivo dose-response relationship of immunosuppressive drugs using a mouse heart transplant model: Application to cyclosporine. J Pharmacol Exp Ther 244: 259-262, 1988.

20. Fiedor P, Jin MX, Hardy MA and Oluwole SF: Dependence of acquired systemic tolerance to rat islet allografts induced by intrathymic soluble alloantigens on host responsiveness, MHC differences, and transient immunosuppression in the high responder recipient. Transplantation 63: 279-283, 1997.

21. Oluwole SF, Jin MX, Chowdhury NC, Engelstad K, Ohajekwe OA and James T: Induction of peripheral tolerance by intrathymic inoculation of soluble alloantigens: Evidence for the role of host antigen-presenting cells and suppressor cell mechanism. Cell Immunol 162: 33-41, 1995.

22. Otomo N, Motovama K, Yu S, Shimizu Y, Margenthaler JA, Tu F and Flye MW: Intrathymic alloantigen-mediated tolerant, completely MHC-mismatched mouse hearts are specifically rejected by adoptively transferred in vitro-sensitized anti-class I L(d+)-specific 2C cells. Transplant Proc 33: 159-160, 2001.

23. Strober S: Protective conditioning against GVHD and graft rejection after combined organ and hematopoietic cell transplantation. Blood Cell Mol Dis 40: 48-54, 2008. 
24. Arima T, Lehmann M and Flye MW: Induction of donor specific transplantation tolerance to cardiac allografts following treatment with nondepleting (RIB 5/2) or depleting (OX-38) anti-CD4 $\mathrm{mAb}$ plus intrathymic or intravenous donor alloantigen. Transplantation 63: 284-292, 1997.

25. Gopinathan R, DePaz HA, Oluwole OO, Ali AO, Garrovillo M, Engelstad K, Hardy MA and Oluwole SF: Role of reentry of in vivo alloMHC peptide-activated $\mathrm{T}$ cells into the adult thymus in acquired systemic tolerance. Transplantation 72: 1533-1541, 2001.

26. Hillebrands JL, Raué HP, Klatter FA, Hylkema MN, Platteel I, Hardonk-Wubbena A, Nieuwenhuis P and Rozing J: Intrathymic immune modulation prevents acute rejection but not the development of graft arteriosclerosis (chronic rejection). Transplantation 71: 914-924, 2001.

27. Kobayashi E, Kamada N, Delriviere L, Lord R, Goto S, Walker NI, Enosawa S and Miyata M: Migration of donor cells into the thymus is not essential for induction and maintenance of systemic tolerance after liver transplantation in the rat Immunology 84: 333-336, 1995.

28. Trani J, Moore DJ, Jarrett BP, Markmann JW, Lee MK, Singer A, Lian MM, Tran B, Caton AJ and Markmann JF: CD25+ immunoregulatory $\mathrm{CD} 4 \mathrm{~T}$ cells mediate acquired central transplantation tolerance. J Immunol 170: 279-286, 2003.

29. Chowdhury NC, Murphy B, Sayegh MH, Hardy MA and Oluwole SF: Induction of transplant tolerance by intrathymic inoculation of synthetic MHC class I allopeptides. Transplant Proc 29: 1136, 1997

30. Sonntag KC, Emery DW, Yasumoto A, Haller G, Germana S, Sablinski T, Shimizu A, Yamada K, Shimada H, Arn S, et al Tolerance to solid organ transplants through transfer of MHC class II genes. J Clin Invest 107: 65-71, 2001.

31. Spriewald BM, Ensminger SM, Jenkins S, Morris PJ and Wood KJ: Intrathymic delivery of plasmid-encoding endoplasmic reticulum signal-sequence-deleted MHC class I alloantigen can induce long-term allograft survival. Transpl Int 17: 458-462, 2004.

32. Ando Y, Beck Y, Ichikawa N, Meigata K, Nomura Y, Nishimura $\mathrm{Y}$, Tomikawa $\mathrm{S}$ and Takiguchi $\mathrm{M}$ : Induction of long-term heart graft survival in HLA class I transgenic mice by intrathymic injection of HLA class I peptides. Transplant Proc 30: 3890-3891, 1998.
33. del Rio ML, Pabst O, Ramirez P, Penuelas-Rivas G, Förster R and Rodriguez-Barbosa JI: The thymus is required for the ability of FTY720 to prolong skin allograft survival across different histocompatibility MHC barriers. Transpl Int 20: 895-903, 2007.

34. Siemionow M, Izycki D, Ozer K, Ozmen S and Klimczak A: Role of thymus in operational tolerance induction in limb allograft transplant model. Transplantation 81: 1568-1576, 2006.

35. Yamamoto S, Teranishi K, Kamano C, Samelson-Jones E, Arakawa H, Nobori S, Okumi M, Houser S, Shimizu A, Sachs DH and Yamada K: Role of the thymus in transplantation tolerance in miniature swine: V. Deficiency of the graft-to-thymus pathway of tolerance induction in recipients of cardiac transplants. Transplantation 81: 607-613, 2006

36. Yamada K, Vagefi PA, Utsugi R, Kitamura H, Barth RN, LaMattina JC and Sachs DH: Thymic transplantation in miniature swine: III. Induction of tolerance by transplantation of composite thymokidneys across fully major histocompatibility complex-mismatched barriers. Transplantation 76: 530-536, 2003.

37. Nobori S, Samelson-Jones E, Shimizu A, Hisashi Y, Yamamoto S, Kamano C, Teranishi K, Vagefi PA, Nuhn M, Okumi M, et al: Long-term acceptance of fully allogeneic cardiac grafts by cotransplantation of vascularized thymus in miniature swine. Transplantation 81: 26-35, 2006

38. Viret C, Sant'Angelo DB, He X, Ramaswamy $H$ and Janeway CA Jr: A Role for accessibility to self-peptide-self-MHC complexes in intrathymic negative selection. J Immunol 166 : 4429-4437, 2001.

39. Pullen JK, Horton RM, Cai ZL and Pease LR: Structural diversity of the classical H-2 genes: K, D, and L. J Immunol 148: 953-967, 1992.

40. Chowdhury NC, Jin MX, Hardy MA and Oluwole SF: Donor-specific unresponsiveness to murine cardiac allografts induced by intrathymic-soluble alloantigens is dependent on alternate pathway of antigen presentation. J Surg Res 59: 91-96, 1995.

41. Knechtle SJ, Wang J, Graeb C, Zhai Y, Hong X, Fechner JH Jr and Geissler EK: Direct MHC class I complementary DNA transfer to thymus induces donor-specific unresponsiveness, which involves multiple immunologic mechanisms. J Immunol 159: 152-158, 1997.

42. Geissler EK, Scherer MN and Graeb C: Soluble donor MHC class I gene transfer to thymus promotes allograft survival in a high-responder heart transplant model. Transpl Int 13 (Suppl 1): S452-S455, 2000. 